Kumawula, Vol. 3, No.2, Agustus 2020, Hal 298 - 309

DOI: https://doi.org/10.24198/kumawula.v3i2.28181

ISSN 2620-844X (online)

Tersedia online di http://jurnal.unpad.ac.id/kumawula/index

\title{
PERANAN E-COMMERCE UNTUK MENINGKATKAN DAYA SAING USAHA MIKRO KECIL DAN MENENGAH (UMKM) SAMBAL DI JAWA TIMUR
}

\author{
Yenny Sugiarti $^{1^{*}}$, Yenny Sari ${ }^{2}$, Mochammad Arbi Hadiyat ${ }^{3}$ \\ ${ }^{1}$ Jurusan Akuntansi, Fakultas Bisnis dan Ekonomika, Universitas Surabaya \\ Jalan Raya Kalirungkut Surabaya, 60294 \\ 2,3 Jurusan Teknik Industri, Fakultas Teknik, Universitas Surabaya \\ Jalan Raya Kalirungkut Surabaya, 60294 \\ *yenny_s@staff.ubaya.ac.id
}

\begin{abstract}
ABSTRAK
Usaha Mikro Kecil dan Menengah harus memiliki daya saing supaya tetap bertahan. Salah satu strategi untuk meningkatkan daya saing adalah menggunakan media pemasaran yang tepat yang menggabungkan antara media pemasaran offline (konvensional) dan online. Media pemasaran yang dimiliki oleh Usaha Mikro Kecil Menengah DEDE SATOE sebelumnya masih konvensional yaitu dilakukan secara offline, sehingga pertumbuhan pasarnya juga sangat lambat. Tim Program Pengembangan Produk Unggulan Daerah betujuan membantu DEDE SATOE melengkapi media promosinya dengan media promosi online untuk memperluas pangsa pasar serta mempercepat pertumbuhannya. Tahap yang dilakukan adalah analisis e-commerce platform, pendaftaran, pelatihan dan pendampingan penggunaan e-commerce platform, serta dilakukan pemantauan dan rekapitulasi hasil penjualan melalui e-commerce platform tersebut. Hasil yang diperoleh adalah jumlah transaksi dan jumlah produk yang terjual di 5 online platform yaitu Tokopedia, Bukalapak, Shopee, Lazada dan Blibli mengalami peningkatan signifikan dari periode Juli-Desember 2019 ke Januari-Mei 2020. Di masa datang UMKM harus lebih fokus untuk mengelola penjualan melalui e-commerce platform supaya lebih optimal.
\end{abstract}

Keyword: media pemasaran; e-commerce platform; promosi; Usaha Mikro Kecil dan Menengah

\begin{abstract}
Small and medium-sized enterprises (SMEs) must have competitiveness to survive. One strategy to improve competitiveness is to use the right marketing media that combines offline (conventional) and online marketing media. The marketing media owned by DEDE SATOE previously were still conventional, which was done offline, so that the market growth was also very slow. The Program Pengembangan Produk Unggulan Daerah Team helps DEDE SATOE complete its promotional media with online promotional media to expand market share and accelerate its growth. The stage taken is an analysis of e-commerce platforms, registration, training and assistance in using e-commerce platforms, and monitoring and recapitulation of sales results through the e-commerce platforms. The results are the number of transactions and the number of products sold on 5 online platforms namely Tokopedia, Bukalapak, Shopee, Lazada and Blibli experienced a significant increase from the period July-December 2019 to January-May 2020. In the future DEDE SATOE should focus more on managing sales through e-commerce platforms to be more optimal.
\end{abstract}

Keyword: e-commerce platform; marketing media; promotion; small and medium-sized enterprises 


\section{Pendahuluan}

Usaha Mikro Kecil dan Menengah (UMKM) merupakan pilar perekonomian di Indonesia. Tahun 2018, jumlah UMKM di Indonesia mencapai 99,99\% dari total seluruh bisnis yang ada di Indonesia dan memberikan sumbangan 57,3\% dari total Pendapatan Domestik Bruto (Kementerian Koperasi dan UMKM, 2018). Hal Ini menunjukkan bahwa UMKM merupakan penggerak perekonomian dan memberikan kontribusi signifikan dalam perekonomian Indonesia. UMKM juga merupakan usaha padat karya, sehingga mampu menyerap tenaga kerja sehingga hal ini sangat membantu pemerintah untuk mengatasi jumlah pengangguran di Indonesia.

Sayangnya masih banyak UMKM yang belum memiliki daya saing yang cukup baik, apalagi menghadapi pandemi COVID-19. Karena memiliki keterbatasan modal, sumber daya manusia dan pemahaman bisnis, maka tidak sedikit UMKM yang mengalami kebankrutan saat pandemi COVID-19. Di kabupaten Lebak, ada 2000 UMKM yang harus menutup bisnisnya akibat pandemi COVID-19 (Tempo, 2020). Berdasarkan hasil survey ILO terhadap 571 UMKM ILO di Indonesia pada tahun 2020, 90\% mengalami kesulitan arus kas keuangan (cash flow) amat terganggu, dan 52\% UMKM kehilangan pendapatan hingga 50\% dari yang mereka biasa peroleh. Sekitar 63\% UMKM terpaksa harus menghentikan karyawannya (Kabar Bisnis, 2020).

UMKM yang ingin bertahan mulai beralih ke bisnis online untuk menggantikan pendapatan yang didapatkan secara offline, karena pembatasan pergerakan manusia pada masa COVID-19. Berdasarkan survey yang dilakukan oleh UGM terhadap 60 UMKM di Yogyakarta tahun 2020, hanya 25,5\% UMKM yang mempertahankan media pemasaran konvensional di tengah pandemi COVID-19. Sisanya mulai menggunakan media sosial dan $e$ commerce (UGM, 2020). Survey yang dilakukan oleh UMKM Indonesia tahun 2020 juga menyatakan bahwa masih ada 8\% UMKM yang mengalami peningkatan omset di tengah pandemi COVID-19. Keseluruhan UMKM tersebut sudah Go Online, atau sudah memasarkan produknya secara online (UMKM Indonesia, 2020)

Usaha untuk membantu UMKM sudah dilakukan oleh pemerintah mulai beberapa tahun terakhir, khususnya oleh Kementerian Koperasi dan Usaha Kecil Menengah dan Kementerian Komunikasi dan Informatika. Pada tahun 2018, dengan melibatkan Marketplace (Bukalapak, Blibli.com, Tokopedia, Shopee, Blanja dan Grab Food) telah tercapai sejumlah 4.914.413 UMKM yang telah Go Online melalui kegiatan On Boarding ke Marketplace. (Kominfo, 2018). Kementerian Kominfo, dan pemangku kepentingan (utamanya para pengelola marketplace) pada Maret 2017 telah merekrut 100 ribu UMKM di 30 kota untuk go-online. Lewat program ini, pemerintah berkomitmen untuk meng-online-kan 8 juta UMKM sampai tahun 2020 (Kominfo,2017). Usaha ini tentu saja akan sangat membantu 
UMKM untuk bertahan di masa pandemi COVID-19. Tanggung jawab tersebut tidak hanya milik pemerintah. Perguruan tinggi juga memiliki tanggung jawab untuk membantu UMKM siap menghadapi era digital dan berbisnis online, melalui kegiatan pengabdian kepada masyarakat.

Universitas Surabaya, melalui hibah pengabdian masyarakat PPPUD Sambal di Jawa Timur mendampingi UMKM Sambal DEDE SATOE untuk meningkatkan daya saingnya di pasar global selama tiga tahun mulai 2018-2020. UMKM ini didirikan oleh Dra. Susilaningsih, MM. pada tahun 2011 dan beralamat di Jl. Tenggilis Timur VI/DD-1, Surabaya. UMKM DEDE SATOE merupakan usaha yang bergerak di bidang industri makanan dengan produk utama adalah sambal dengan berbagai varian rasa (gambar 1). Produk yang dihasilkan mitra adalah produk makanan dan minuman yang merupakan salah satu Komoditi Produk dan Jasa Unggulan (KPJU) Jawa Timur yang ditetapkan oleh Bank Indonesia di tahun 2018. RPJMD Kota Surabaya 2016-2021 menyebutkan bahwa kontribusi industri makanan dan minuman terhadap PDRB adalah 14,16\%. Ini menyebutkan bahwa sambal sebagai salah satu produk makanan juga turut berkontribusi terhadap PDRB kota Surabaya. Produk UMKM ini sebenarnya memiliki keunggulan, yaitu telah tersertifikasi HACCP ( Hazard Analysis Critical Control Point) sehingga proses produksinya sangat higienis. Hal ini menjadi sangat penting bagi pelanggan terutama di tengah pandemi COVID19.

\section{Gambar 1. Produk UMKM DEDE SATOE}

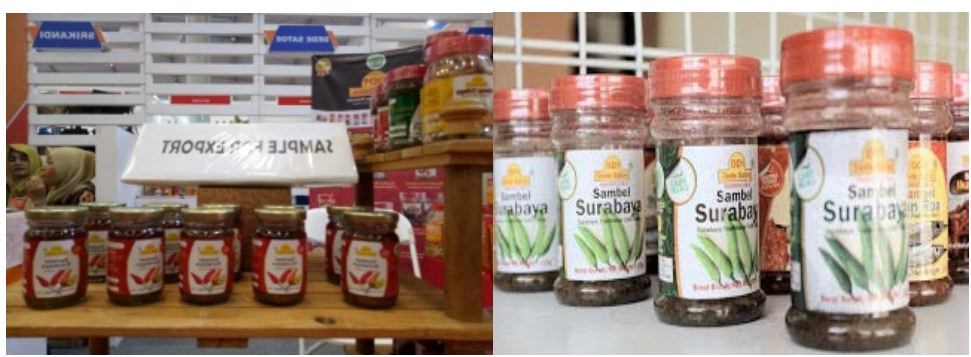

Area pemasaran utama dari UMKM DEDE SATOE adalah wilayah Surabaya dan Sidoarjo. Konsumen utama UMKM tersebut adalah golongan menengah. Hal ini dibuktikan dengan sasaran gerai outlet konsinyasi yang dipilih oleh UMKM DEDE SATOE adalah gerai retail yang cukup ekslusif seperti Keris Gallery di bandara internasional, Chicco, Bonet, Carrefour, Ranch Market, Gelael Group, dan Farmer. UMKM tersebut juga merupakan binaan dari beberapa dinas pemerintah seperti Dinas Perindustrian, Dinas Koperasi dan Telkom sehingga kadang diberi kesempatan mengikuti pameran di dalam \& luar negeri.

\section{Identifikasi Masalah dan Solusi}


Metode pemasaran yang dipilih oleh UMKM DEDE SATOE sebagian besar melalui gerai retail sehingga sangat bergantung pada penjualan masing-masing gerai retail. Gerai retail masih terbatas wilayah Surabaya dan Sidoarjo. Perluasan pangsa pasar lebih banyak mengandalkan event pameran yang disponsori oleh dinas pemerintah setempat. Metode pemasaran konvensional dan banyaknya pesaing yang saat ini memproduksi sambal juga membuat ini membuat pertumbuhan pasar UMKM ini sangat lambat. Pada tahun 2018 hanya ada tambahan 1 outlet retail yang berhasil ditambahkan. Di tahun 2020 ini, penjualan secara offline menurun drastis akibat pandemi COVID-19. Beberapa gerai retail bahkan menghentikan sementara pesanannya.

Di tahun 2018, UMKM DEDE SATOE telah mencoba menggunakan platform online BUKALAPAK dan pemasaran melalui Instagram dan Facebook namun belum aktif. Hal ini disebabkan karena kurangnya kompetensi sumber daya manusia yang dimiliki oleh UMKM, sehingga pada tahun tersebut hanya ada 19 transaksi online melalui Bukalapak. Berdasarkan survey yang dilakukan Deloitte di tahun 2018 terhadap 2000 responden di 5 kota besar di Indonesia menyatakan bahwa 26\% responden menyatakan lebih menyukai belanja online karena lebih praktis, 17\% menyatakan bisa mendapatkan harga barang lebih murah, dan 13\% menyatakan lebih mudah untuk mencari produk (Deloitte, 2018). Hal ini sebenarnya merupakan peluang yang sangat bagus bagi UMKM DEDE SATOE untuk memperluas dan mempercepat pertumbuhan pasarnya. Program PPPUD Sambal di Jawa Timur berupaya untuk mengatasi kelemahan metode pemasaran konvensional (memberikan solusi) sekaligus membantu UMKM untuk menangkap peluang perluasan pangsa pasar melalui media pemasaran online melalui optimalisasi e-commerce platform dengan melaksanakan beberapa tahapan yang akan dijelaskan pada bagian berikutnya.

\section{Metode}

E-commerce platform dipilih sebagai solusi karena implementasinya cukup murah, tidak membutuhkan investasi yang besar, dan mudah dipahami oleh pengelola UMKM. Pelanggan saat ini juga lebih menyukai penggunaan e-commerce platform. Berdasarkan survey yang dilakukan Katadata Insight Center di tahun 2018 terhadap 508 konsumen ecommerce di Indonesia, konsumen lebih menyukai berbelanja di e-commerce platform seperti Tokopedia, Shopee dan lainnya karena banyak diskon, gratis ongkos kirim, flash sale dan aman transaksi pembayarannya (Katadata,2018). Berikut ini akan dijelaskan waktu dan tempat pelaksanaan, sumber daya yang dibutuhkan dan tahapan pelaksanaannya.

\section{Waktu dan Tempat Pelaksanaan}


Pelaksanaan kegiatan dilakukan di UMKM DEDE SATOE yang bertempat di Tenggilis Mejoyo dan di Universitas Surabaya. Kegiatan ini dilaksanakan oleh tiga tim dosen PPPUD (Program Pengembangan Produk Unggulan Daerah) dan dibantu oleh empat orang mahasiswa sebagai pelaksana kegiatan. Waktu pelaksanaan kegiatan dilaksanakan mulai Mei sampai Agustus 2019, dan hasil implementasi direkam dan dipantau sampai Mei 2020.

\section{Sumber Daya yang Dibutuhkan}

Pelaksanaan aktivitas ini membutuhkan beberapa sarana fisik dan keterlibatan sumber daya manusia yang dimiliki oleh UMKM DEDE SATOE. Sarana fisik yang dibutuhkan adalah sebuah personal computer/notebook yang terkoneksi dengan internet, dokumentasi persyaratan umum yang disyaratkan sebagai peserta e-commerce platform seperti foto, KTP dan nomor rekening pemilik, dan materi yang akan diunggah di e-commerce flatform berupa deskripsi singkat UMKM, foto produk, deskripsi dan harga produk. Aktivitas ini juga membutuhkan seorang staf dari UMKM yang nantinya akan dibekali pengetahuan mengenai administrasi e-commerce platform sehingga aktivitas ini dapat terus dijalankan meskipun program pengabdian masyarakat telah berakhir. UMKM DEDE SATOE menyediakan seorang staf administrasi yang nantinya secara intensif akan dilatih dan didampingi oleh tim PPPUD. Sarana fisik juga telah disiapkan mandiri oleh UMKM DEDE SATOE

\section{Tahapan pelaksanaan}

Adapun tahapan pelaksanaan kegiatan dapat dilihat pada gambar 2 berikut ini:

\section{Gambar 2. Tahapan Pelaksanaan}




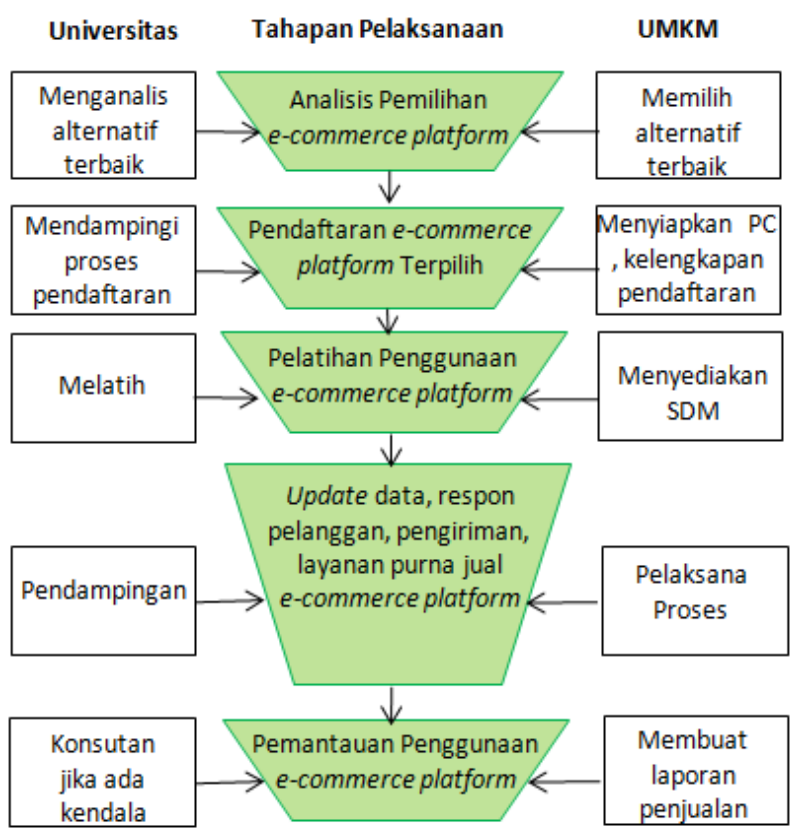

Pada tahapan pertama, tim PPPUD melakukan riset pasar e-commerce platform dengan mencari informasi banyaknya pengunjung, user aktif yang mengakses masing-masing e-commerce platform serta banyaknya unduhan masing-masing e-commerce platform di appstore dan playstore. Tim PPPUD juga menyajikan kelebihan dan kelemahan tiap alternatif pilihan. Berdasarkan analisis tersebut, ditetapkan 5 pilihan terbaik yang nantinya akan digunakan oleh UMKM DEDE SATOE. Tahapan ini dilaksanakan pada bulan Mei 2019.

Pada tahap selanjutnya tim PPPUD menginformasikan sarana dan kelengkapan yang harus disiapkan. UMKM DEDE SATOE akan menyiapkan sarana implementasi promosi $e$ commerce platform seperti personal computer, notebook dan handphone serta dokumentasi perlengkapan lainnya seperti materi yang harus diupload berupa foto dan deskripsi singkat produk, KTP, foto dan nomor rekening untuk menampung dana hasil penjualan dari $e$ commerce platform. Setelah semua siap tim PPPUD bersama UMKM melakukan pendaftaran sampai masing-masing e-commerce platform siap digunakan untuk transaksi. Tahapan ini dilaksanakan pada bulan Juni 2019

Di tahap ketiga dan ke empat tim PPPUD melaksanakan pendampingan penggunaan masing-masing e-commerce platform. Penggunaan yang dimaksud disini adalah proses update barang, strategi pemasaran, penanganan transaksi mulai penerimaan pesanan sampai barang dikirimkan serta layanan purna jual berupa respon terhadap komentar dan komplain pelanggan. Tahapan ini dilakukan pada bulan Juni dan Juli 2019. 
Tahap selanjutnya adalah dilakukan pemantauan terhadap efektivitas penjualan pada masing-masing online platform. Tim PPPUD juga memberikan konsultasi kepada UMKM jika mengalami kendala selama menggunakan online platform. UMKM merekap data penjualan melalui e-commerce platform setiap bulan untuk melihat kinerja penjualan di masing-masing platform. Proses pemantauan ini dilakukan sampai Mei 2020.

\section{Hasil}

Hasil pelaksanaan tiap tahapan yang telah dijelakan pada bagian metode pelaksanaan akan dijelaskan sebagai berikut:

Hasil riset pasar e-commerce platform dilakukan dengan mencari informasi banyaknya pengunjung, banyaknya pengguna aktif yang mengakses masing-masing e-commerce platform, banyaknya unduhan masing-masing e-commerce platform di appstore dan playstore serta kelebihan dan kelemahan tiap platform. maka ditetapkan bahwa ada 6 alternatif online platform yang nantinya dapat digunakan adalah Tokopedia, Bukalapak, Shopee, Lazada, JD.id dan Blibli. UMKM menetapkan memilih 5 platform yaitu Tokopedia, Bukalapak, Shopee, Lazada, dan Blibli karena penggunaannya relatif mudah, tingkat kepuasan pelanggan terhadap platform tersebut cukup tinggi dan banyak varian produknya, khususnya produk makanan khas Indonesia seperti sambal. Detil hasil analisis data dapat dilihat pada tabel 1.

Tabel 1. Hasil Analisis Riset Pasar E-commerce platform

\begin{tabular}{|c|c|c|}
\hline Indikator & 6 Besar E-commerce platform & Sumber \\
\hline Jumlah pengunjung & $\begin{array}{c}\text { Tokopedia, Bukalapak, Shopee, } \\
\text { Lazada, Blibli dan JD.id }\end{array}$ & $\begin{array}{c}\text { Katadata (2019), } \\
\text { Tempo (2019), } \\
\text { Technobusiness (2018) }\end{array}$ \\
\hline $\begin{array}{c}\text { Jumlah pengguna aktif } \\
\text { terbanyak }\end{array}$ & $\begin{array}{c}\text { Tokopedia, Bulalapak, Shopee, } \\
\text { Lazada, JD.id, Blibli }\end{array}$ & iPrice (2019) \\
\hline $\begin{array}{c}\text { Banyaknya unduhan di } \\
\text { appstore dan playstore }\end{array}$ & $\begin{array}{c}\text { Tokopedia, Bulalapak, Shopee, } \\
\text { Lazada, JD.id, Blibli }\end{array}$ & $\begin{array}{c}\text { Sindonews (2019), } \\
\text { Katadata (2019) }\end{array}$ \\
\hline
\end{tabular}

Setelah dilakukan pendaftaran pada kelima platform tersebut, maka pada Juni 2019 produk UMKM DEDE SATOE sudah tersedia di 5 platform tersebut seperti tampak pada gambar 3 dan 4.

Gambar 3. Tampilan Produk di Platform Shopee dan Tokopedia 

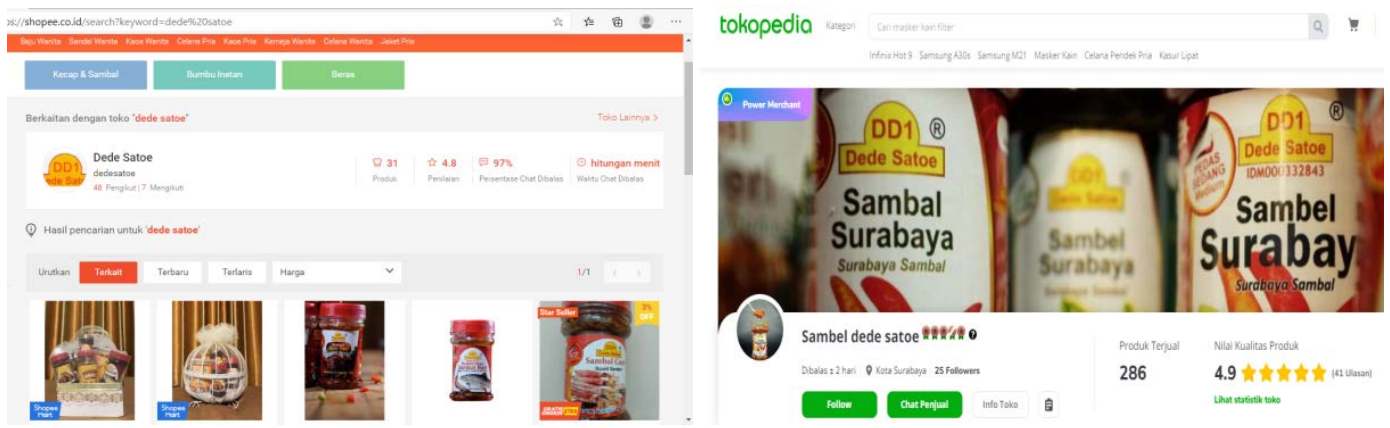

Gambar 4. Tampilan Produk di Platform Lazada, Blibli dan Bukalapak

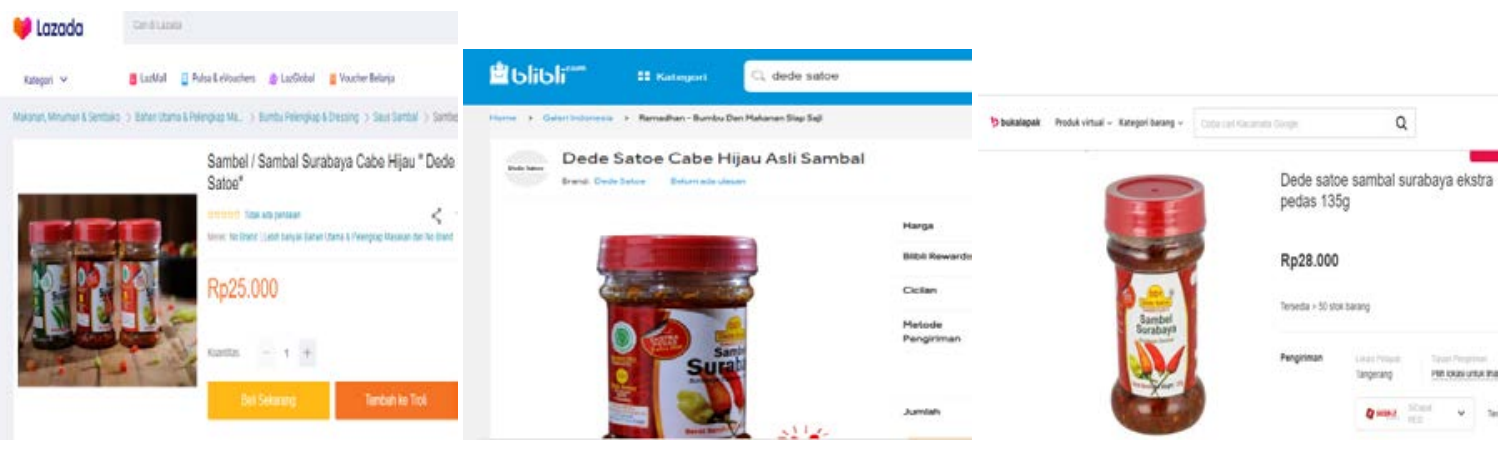

Saat proses pendaftaran tim PPPUD memberikan edukasi sekaligus membantu UMKM melaksanakan pendaftaran di lima e-commerce platform yang meliputi proses download aplikasi masing-masing platform, registrasi, mengisi deskripsi toko, upload foto-foto produk beserta isian deksripsi produk, serta memasukkan harga jual sehingga proses pendaftaran berhasil dan toko siap menerima pembeli.

Selama bulan Juni dan Juli 2019, tim PPPUD melaksanakan pendampingan penggunaan e-commerce platform sehingga karyawan yang menangani penjualan di $e$ commerce platform benar-benar menguasai proses penerimaan pesanan, pengepakan dan pelabelan sesuai aturan dari masing-masing e-commerce platform, pengiriman produk ke ekspedisi, membalas chat dari pelanggan, menangani komplain, memantau penjualan dan menarik data penjualan dari masing-masing platform serta membantu pemilik dalam menetapkan strategi promosi di masing-masing platform. Pada gambar 5 dan 6, tampak proses pendampingan yang dilakukan oleh tim kepada UMKM DEDE SATOE.

\section{Gambar 5. Pendampingan}




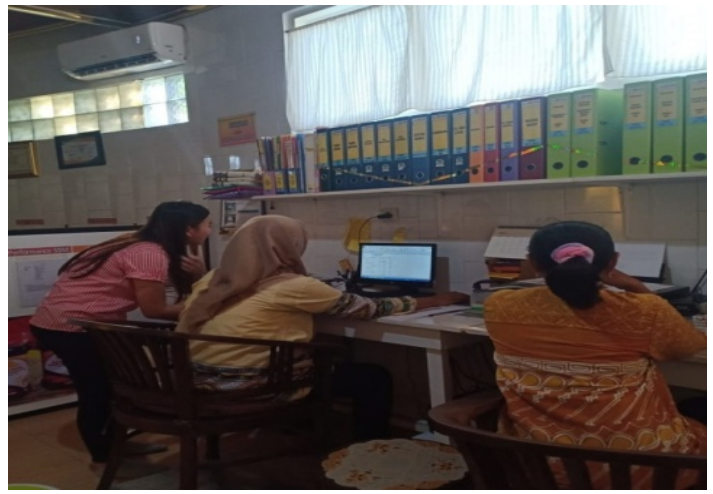

\section{Gambar 6. Pelatihan Penggunaan E-commerce platform}

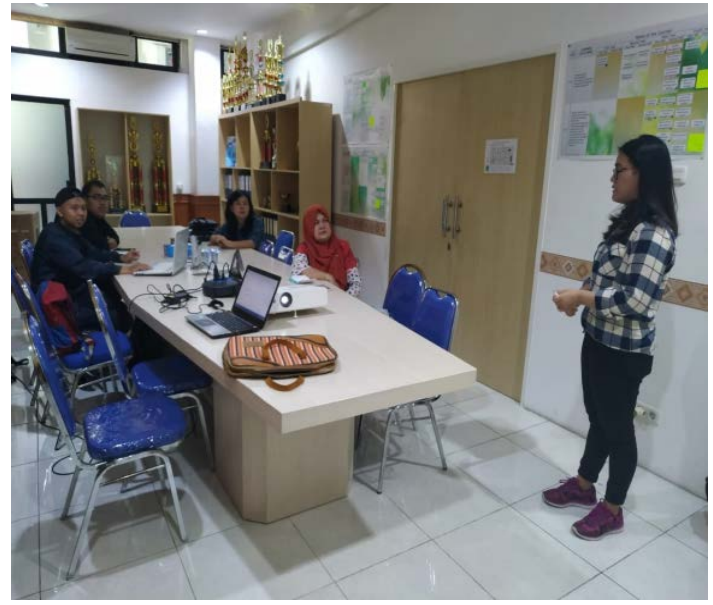

Selanjutnya dilakukan pemantauan terhadap efektivitas penggunaan e-commerce platform. Berdasarkan hasil rekapitulasi transaksi penjualan online sampai dengan Mei 2020, hasilnya dapat dilihat pada tabel 2.

Tabel 2 menunjukkan ada peningkatan yang cukup signifikan baik dari sisi jumlah transaksi maupun jumlah yang dijual secara online di e-commerce platform. Jumlah transaksi di bulan Januari - Mei 2020 meningkat 160 \% dibanding pada bulan Juli - Desember 2019. Jumlah botol yang dijual Januari - Mei 2020 meningkat 178 \% dibanding pada bulan Juli Desember 2019 (gambar 7). Bahkan pada masa pandemi COVID-19 penjualan di online platform naik tajam. Pada bulan April 2020 nilai penjualan mencapai Rp3.051.100,-, sedangkan pada bulan Mei 2020 Rp2.249.375,-.

Tabel 2. Penjualan di E-commerce platform

\begin{tabular}{|l|r|r|r|r|}
\hline \multirow{2}{*}{ Platform } & \multicolumn{2}{|c|}{ Juli- Des 2019 } & \multicolumn{2}{c|}{ Jan - Mei 2020 } \\
\cline { 2 - 5 } & Transaksi & Botol & Transaksi & \multicolumn{1}{c|}{ Botol } \\
\hline Bukalapak & 10 & 25 & 16 & 50 \\
\hline Tokopedia & 10 & 38 & 68 & 161 \\
\hline
\end{tabular}




\begin{tabular}{|l|r|r|r|r|} 
Shopee & 16 & 25 & 17 & 52 \\
\hline Lazada & 1 & 4 & 0 & 0 \\
\hline Blibli & 3 & 6 & 3 & 9 \\
\hline Total & $\mathbf{4 0}$ & $\mathbf{9 8}$ & $\mathbf{1 0 4}$ & $\mathbf{2 7 2}$ \\
\hline
\end{tabular}

Setelah dilakukan evaluasi pada bulan Mei 2020, data menunjukkan ada 3 platform yang paling efektif digunakan yaitu Bukalapak, Tokopedia dan Shopee, sedangkan dua platform lainnya (Lazada dan Blibli) cenderung kurang aktif. Selanjutnya promosi online harus fokus pada 3 platform tersebut (Bukalapak, Tokopedia dan Shopee).

\section{Gambar 7. Peningkatan Penjualan di Online Platform}

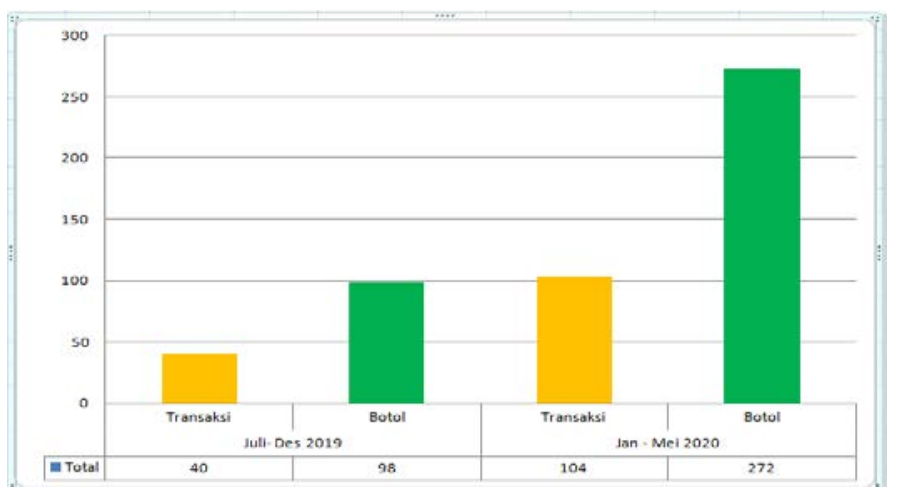

Hasil tersebut di atas menunjukkan bahwa meskipun total nilai penjualan di $e$ commerce platform belum sebesar penjualan offline, namun pertumbuhannya sangat cepat sehingga berpotensi untuk berkembang di masa datang.

Proses pendampingan secara umum berjalan lancar, namun masih ada beberapa kendala yang dihadapi oleh tim PPPUD diantaranya:

- Staf UMKM tidak terlalu banyak waktu belajar dan kurang fokus terhadap materi pelatihan, karena yang bersangkutan juga menangani banyak hal seperti penjualan dan administrasi keuangan

- Staf UMKM kadang masih mengalami kesulitan untuk membalas chat secara proporsional seperti layaknya customer service profesional, sehingga kadang jawaban yang diberikan pada pelanggan kurang memuaskan 
- Jumlah persediaan online masih campur dengan persediaan offline sehingga kadang ada pesanan online yang tidak dapat dipenuhi karena stok sudah terjual melalui media offline. Hal ini tentu saja akan mempengaruhi kepuasan pelanggan

\section{Kesimpulan}

Saat ini mulai terjadi pergeseran perilaku pelanggan. Sebagian pelanggan telah bergeser menjadi pelanggan di e-commerce platform karena berbagai keunggulan diantaranya kemudahan dan keamanan bertransaksi, serta banyaknya promosi menarik yang ditawarkan oleh masing-masing platform. Bagi penjual, keberadaan e-commerce platform juga sangat membantu. Penjual dapat melakukan promosi murah, dan dapat bertransaksi dengan aman. UMKM DEDE SATOE yang selama ini hanya mengandalkan penjualan offline ke berbagai ritel di wilayah Surabaya dan sekitarnya, tidak mengalami pertumbuhan pasar yang signifikan. Oleh sebab itu untuk meningkatkan pertumbuhan pasarnya, terutama di luar Surabaya, metode pemasaran yang dilakukan dilengkapi dengan pemasaran melalui berbagai e-commerce platform yang telah tersedia di Indonesia.

Berdasarkan hasil riset pasar yang dilakukan tim PPPUD, disimpulkan bahwa $e$ commerce platform yang paling potensial untuk digunakan adalah Tokopedia, Bukalapak, Shopee, Lazada dan Blibli. UMKM didampingi melakukan pemasaran melalui lima platform tersebut sehingga mampu mandiri menggunakan kelima platform tersebut untuk bertransaksi. Hasil yang telah dicapai menunjukkan bahwa penetrasi pasar online telah berhasil dilakukan oleh UMKM DEDE SATOE. Di semester dua tahun 2019 telah ada penjualan yang cukup besar dari 3 online platform yaitu Tokopedia, Bukalapak dan Shopee. Jumlah tersebut terus naik tajam di lima bulan pertama di tahun 2020. Hal ini membuktikan bahwa penjualan melalui e-commerce platform cukup efektif untuk meningkatkan penjualan total UMKM, apalagi di tengah pandemi COVID-19 dimana pada masa ini pelanggan lebih menyukai bertransaksi di rumah dibanding harus pergi ke berbagai pusat retail. Pada akhirnya, di jangka panjang hal ini akan meningkatkan daya saing UMKM DEDE SATOE.

Secara umum tidak ada kendala yang dialami tim PPPUD dalam melaksanakan pelatihan dan pendampingan, namun keterbatasan jumlah SDM kadang menyebabkan SDM yang ditugaskan untuk mengelola penjualan di e-commerce platform tidak fokus karena harus melakukan hal lainnya. Di masa datang UMKM perlu lebih fokus dan meluangkan waktu lebih banyak untuk memaksimalkan penggunaan platform tersebut. Kompetensi komunikasi 
juga perlu ditingkatkan sehingga staf yang ditugaskan dapat menjawab pertanyaan pelanggan dengan baik sehingga kepuasan pelanggan tinggi. Persediaan barang yang dijual melalui media pemasaran online juga perlu dipisahkan dengan media pemasaran offline sehingga tidak ada penjualan yang tidak terlayani akibat persediaan (stok) barang tidak tersedia. Kinerja penjualan di lima e-commerce platform juga perlu dievaluasi secara periodik. Jika ada platform yang tidak menguntungkan, supaya lebih fokus, maka UMKM harus memilih $e$ commerce platform yang jumlah penjualannya tinggi.

\section{Ucapan Terima Kasih}

Penulis selaku tim PPPUD mengucapkan terima kasih kepada semua pihak sehingga kegiatan PPPUD dapat terlaksana dengan baik dan artikel ini dapat diselesaikan. Pertama kepada RISTEKDIKTI yang telah memberikan pendanaan berupa hibah PPPUD yang pada saat artikel ini dibuat telah berjalan di tahun ketiga. Kedua kepada Universitas Surabaya yang telah mengijinkan penulis melaksanakan pengabdian masyarakat dalam program PPPUD selama tiga tahun mulai 2018 hingga 2020. Ketiga kepada UMKM DEDE SATOE yang mau menjadi mitra, mau bekerjasama serta memiliki komitmen untuk melaksanakan kegiatan pengabdian masyarakat bersama tim. Semoga kegiatan yang dilakukan serta artikel yang ditulis membawa manfaat bagi banyak pihak.

\section{Daftar Pustaka}

Delloite Consumer Insight Survey. (2019). Sudahkah Pola Belanja Orang Indonesia Bergeser MenujuDigital?, diakses dari https://www2.deloitte.co m/content/dam/Deloitte/id/Documents/about- deloitte/id-about-dip-edition-1-chapter-5idsep2019.pdf

Islami, Nur. (2017). UMKM Online Indonesia Masuk Sarang Raksasa!, Kementerian Komunikasi dan Informatika Republik Indonesia, diakses dari https://kominfo.go.id/content/detail/10686/umkm-online-indonesia-masuk-sarangraksasa/0/sorotan_media 
Kabar Bisnis. (2020). Terhimpit Covid-19, 63 persen UMKM rumahkan dan PHK karyawan, diakses dari https://www. Kabar bisnis.com/read/28100010/terhimpit-covid-19-63persen-umkm-rumahkan-dan-phk karyawan

Katadata Insight Center. (2018). Perilaku Konsumen E-Commerce, diakses dari https://cdn1.katadata.co.id/media/kic/katadata-indonesia-e-commercemapping 2018. pdf

Kementerian Komunikasi dan Informatika Republik Indonesia. (2019). UMKM Go Online, diakses dari https://aptika.kominfo.go.id/2018/11/fasilitasi-8-juta-umkm-go-online/

Kementerian Koperasi dan Usaha Kecil Menengah Republik Indonesia. (2019). Perkembangan Data Usaha Mikro, Kecil, Menengah (UMKM) dan Usaha Besar (UB) tahun 2017-2018, diakses dari http://w ww.depkop.go.id/uploads/laporan/1580223129_PERKEMBANGAN\%20DATA\%20US AHA\%20MIKRO,\%20KECIL,\%20MENENGAH\%20(UMKM)\%20DAN\%20USAHA \%20BESAR\%20(UB)\%20TAHUN\%202017\%20-\%202018.pdf

Tempo. (2020) Pandemi Corona, Ribuan UMKM Warga Baduy Gulung Tikar, diakses dari https://bisnis.tempo.co/read/1343143/pandemi-corona-ribuan-umkm-warga-baduygulung-tikar

UMKM Indonesia (2020). Peluang dan Kebijakan UMKM di Era Pandemi Covid19, diakses dari https://drive.google.com/file/d/1IQ1teY0hMfP_CRjJiunC66gCJJgLsgeD/view?u =sharing

Universitas Gajah Mada. (2020). Dampak Awal Pandemi Covid-19 terhadap UMKM, diakses dari https://pengabdian.ugm.ac.id/wpcontent/uploads/sites/854/2020/05/Dampak-AwalPandemi-COVID-19-terhadap- UMKM.pdf 